\title{
Investigation of Participation Motivation in Sports Activities of Children with Special Educational Needs
}

\author{
Pervin TOPTAŞ DEMİRCí ${ }^{1 \oplus}$ and Kazım ERASLAN ${ }^{2 * \bullet}$ \\ ${ }^{1}$ Mersin University, Erdemli Vocational School, Department of Tourism Animation, Mersin, Turkey \\ ${ }^{2}$ Prof.Dr. Salih Öven Çolakoğlu Primary School, Adana, Turkey \\ *Corresponding author: kazimeraslan5@gmail.com
}

\begin{abstract}
Education is expected to help individuals to be developed at the highest level by revealing their hidden powers and abilities. Sports is one of the important factors that helps children with need special education to take their places in daily life, to connect them to life by socializing, to orient themselves with motivation and to accept the idea that disability is not an obstacle to continue living. In this study, it was aimed to determine sport participation motivation levels of children with special educational needs. Method; descriptive survey model from quantitative research methods was used in the research. A total of 60 (20 Girls, 40 Boys) children from Mersin special education practice schools participated in the study. In the research, a personal information form prepared by the researchers and the "Scale of Motivation for Participation in Sports in Persons with Disabilities (SMPSPD)" developed by Tekkurşun, İlhan, Esentürk and Kan (2018) were used as a data collection tool. In the analysis of the data obtained in the research; Descriptive statistics and t- test, Pearson Moment Correlation, Mann-Whitney U and Kruskal-Wallis tests were used. According to the findings; the mean scores of internal and external motivation of children who participated in sports activities were significantly higher than those who did not participate in sports activities. While there was no significant difference according to gender, a positive significant difference was found between the age and intrinsic motivation level of the children. As a result; It can be concluded that children with special educational needs have high motivation to participate in sports.
\end{abstract}

\section{Keywords}

Special Education, Sports Activities, Sports Participation Motivation

\section{INTRODUCTION}

The obstacle is a disadvantage that negatively affects an individual's adaptation to daily life. Adaptation is about the extent to which social roles can be made. One of the effective mechanisms that help the individual realize his social roles is sports (İlhan, Esentürk \& Yarımkaya, 2016). In this context, there are many factors that affect the participation of people with disabilities in their daily life and their participation in sports. One of these factors is motivation. Motivation is one of the cornerstones of the individual's participation in sports. Although the reasons for participation in sports activities are quite high, complex is one of the most important factors that encourage and maintain participation in sports activity (McDonough and Crocker, 2005). Motivation is a psychological concept that encourages an individual towards a desired goal and is considered a psychological force that includes the intent and direction of a particular behavior (Ball, Bice \& Parry, 2014). Motivations play a key role in all areas of life, as well as participation in sports activity. Motivation is a key factor in shaping our daily behavior. It is important to understand the main reasons that encourage children to participate in sports activities. 
Participation motivation includes the processes of starting, continuing and withdrawing from sports activity (Ciocan, Milon \& Mareş, 2017). For example, the future expectations of children who perceive themselves as successful in sports cause higher motivation and continued participation than those who perceive themselves as unskilled (Marcen, Gimeno, Gomez, Saenz \& Gutierrez, 2013). Children have different reasons to participate in sports (Having fun, developing their skills, getting together etc) boys and girls have similar reasons for participating in sports activities, but these can vary significantly. Motivation is defined as all internal or acquired, conscious or unconscious internal behavior motifs; a pulse that energizes or activates, especially in sports performance, in general human behavior, is the inner urge. According to Golu (2002), motivation is "a subjective objective model of causality that is accumulated, transformed and transmitted in time through learning and education in an internal individual; (Fredricks \& Eccles, 2006). According to the World Disability Report of the World Health Organization, an estimated 95 million children $(5.1 \%)$ between the ages of $0-14$ have a type of disability. Common problems include Autism Spectrum Disorder, Developmental Delay, Behavioral Disorders, and Learning Difficulty (WHO, 2018).

Individuals continue their lives as members of social life with their motoric, social, emotional and cognitive differences. Depending on the inadequacy of the individual and depending on the degree of this inadequacy, movement limitation or lack of sensory losses may make it different from other individuals of the society (Tekkurşun et al. 2018). Being different from others, being disabled, it is called as "disability". Along with the development of sports body and mental health, it includes the desire to rivalry, excitement, contest and prevail in competition according to certain rules (Yücel, 2004). Sports are physical activities that people do within the rules with the determination to fight to win. The person who does sports is more confident, better adapted to his environment, and his mental health is more balanced and organized (İlhan, 2010). Participation in sports is increasingly important in the protection and development of health in children with special educational needs (Demirci et al., 2018).

Undoubtedly, children who need special education also have an active place in sports activities. Sport is a biological, pedagogical and social phenomenon that improves the physical and mental health of the person, increases the communication with the social environment, and brings the person to a certain level mentally and physically. For this reason, sports should be considered as a tool in the realization of the social harmony of individuals who need special education (İlhan, 2008). Many people with disabilities are unable to participate in sports on a regular basis, which may increase the likelihood of developing secondary health problems. Therefore, there is a need for a source of information on the challenges and facilitators for sports participation (Jaarsma et al. 2014). According to Tenenbaum and Eklund (2007), they argue that the biggest problem in the sports participation of individuals with disabilities is the lack of time and motivation. One of the important elements that helps the acceptance of the idea that the children who need special education are socially connected to life, motivated by their goals, and the idea that their disability is not an obstacle to continue life is ensuring participation in sports. In this study, it was aimed to determine sport participation motivation levels of children with special educational needs.

\section{MATERIALS AND METHODS}

In this context, descriptive survey model from quantitative research methods was used in the research. A total of 60 children from Mersin special education practice schools participated in the study. A personal information form prepared by the researchers and the "Scale of Motivation for Participation in Sports in Persons with Disabilities (SMPSPD)" developed by Tekkurşun, İlhan, Esentürk and Kan (2018) were used as a data collection tool.

\section{Participants}

The universe of the study consists of all children with learning disabilities studying in Mersin special education practice institutions, while the sample consists of 60 children from application schools. In this context, those who have actively participated in school sports competitions for at least two years as a criterion in the selection of participants are included. These children consist of 60 children, 40 Boys and 20 
Girls, who have participated in sports activities and did not do sports. Their mean boy age was $(13,0 \pm 0,1)$, Height was $(155 \pm 0,5)$, Weight $(45,7 \pm 6.4)$ and the mean body mass index (BMI) was $(23,4 \pm 2,5)$ and mean girls age was $(12,6 \pm 0,3)$, Height was $(151 \pm 0,6)$, Weight $(46,1 \pm 6.1)$ and the mean body mass index (BMI) was $(24,6 \pm 2,7)$. The informed consent has been given by the legal guardians of the children who were going to become subjects of this research. The scale was applied and the data was collected according to the ethical standards of application and collection of information when using a scale. The flow diagram showing children with learning disabilities participating in the study is shown in Fig1.

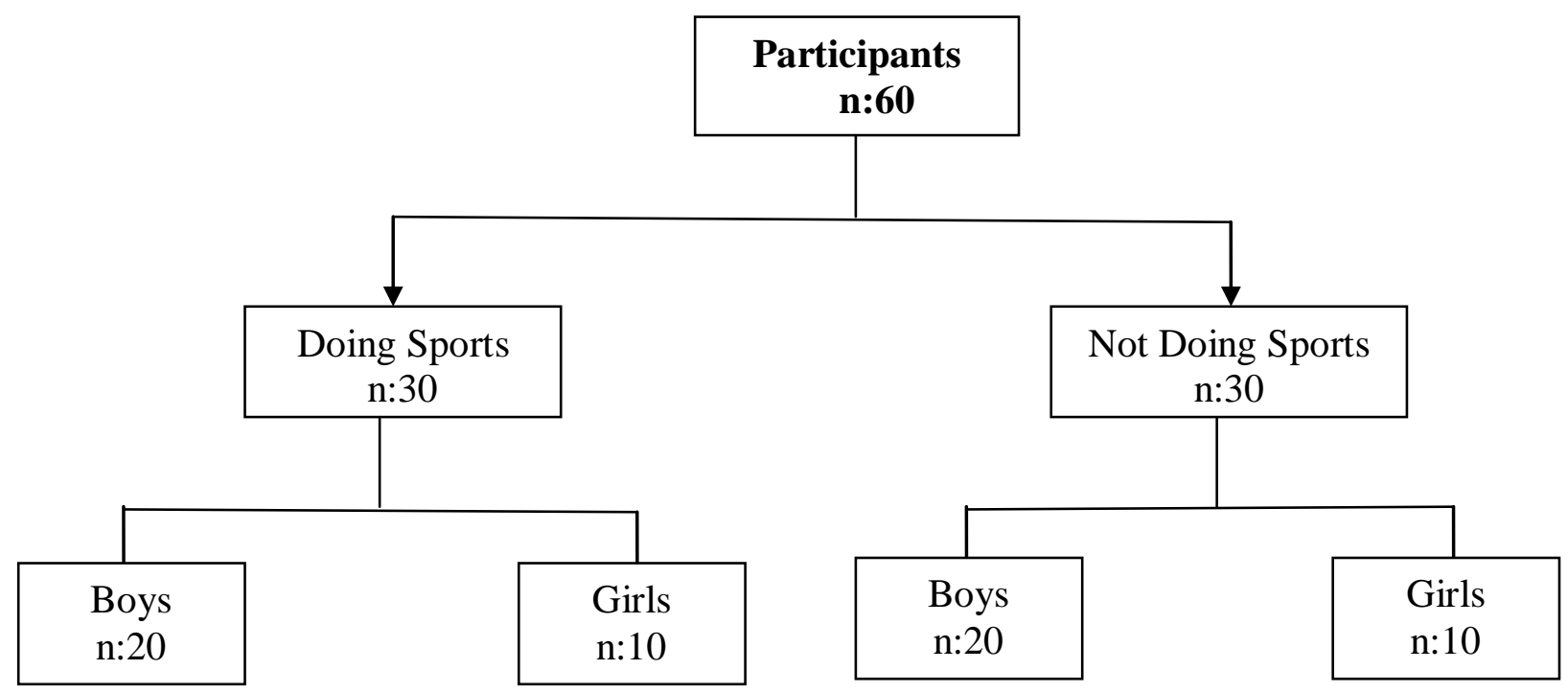

Fig 1. Flow showing children with learning disabilities participating in the study.

\section{Data Collection Tool}

\section{Scale of Motivation for Participation in Sports in Persons with Disabilities (SMPSPD)}

As the data collection tool, "Personal Information Form" created by the researchers and "Sports Participation Motivation Scale for Disabled Individuals (SMPSPD)", which was developed by Tekkurşun, İlhan, Esentürk and Kan (2018), were used as data collection tools. The scale includes the first 12 items under the name "Internal Motivation", 5 items under the "External Motivation" and the last 5 items under the name "Non-Motivation". The non-motivation factor consists of inverse substances. According to the data obtained from the participants, the Cronbach alpha value of Internal Motivation dimension, ".83" Cronbach alpha value of External Motivation dimension was calculated as ".87" and Cronbach alpha value of Non-Motivation dimension was calculated as ".88".

\section{Statistical Analyses}

All statistical analyzes were done with SPSS 22.0 version. In the analysis of the data obtained in the research; descriptive statistics and test, Pearson Moment Correlation Test were used.

When the data does not show normal distribution; Mann-Whitney $\mathrm{U}$ and Kruskal-Wallis tests were used. Significance was accepted as $p<0.05$.

\section{RESULTS}

In the study, no significant difference was observed between the ages of boys and girls who doing and not doing sports. However, when it was evaluated in terms of Height $(\mathrm{P}<0.05)$, Weight $(\mathrm{P}$ $<0.05)$ and BMI $(\mathrm{P}<0.01)$, it was determined that it was significant in favor of those doing sports (Fig. 1,2).

It was determined that the average of intrinsic and extrinsic motivation points of children who do sports is significantly higher than those who do not do sports (Table 1).

While no significant difference was found according to gender, a positive relationship was found between children age and intrinsic motivation level (Table 2,3). 


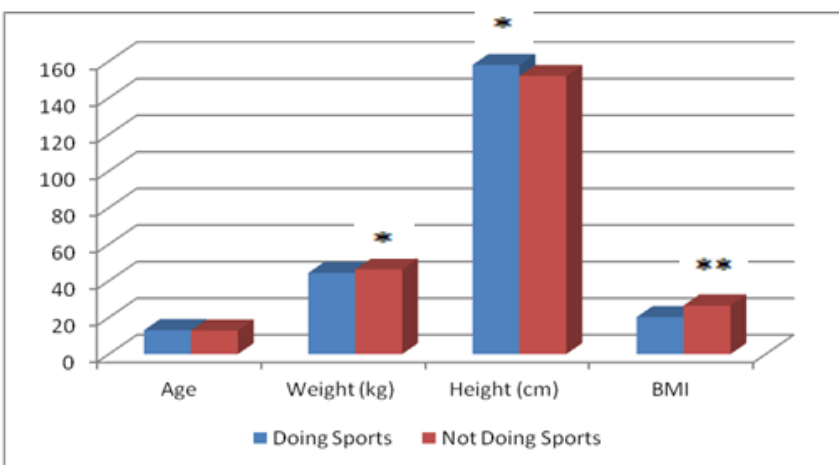

$* \mathrm{P}<0.05, * * \mathrm{P}<0.01$, Body Mass İndex (BMI)

Fig. 1. Demographic Characteristics of Boys with special educational needs

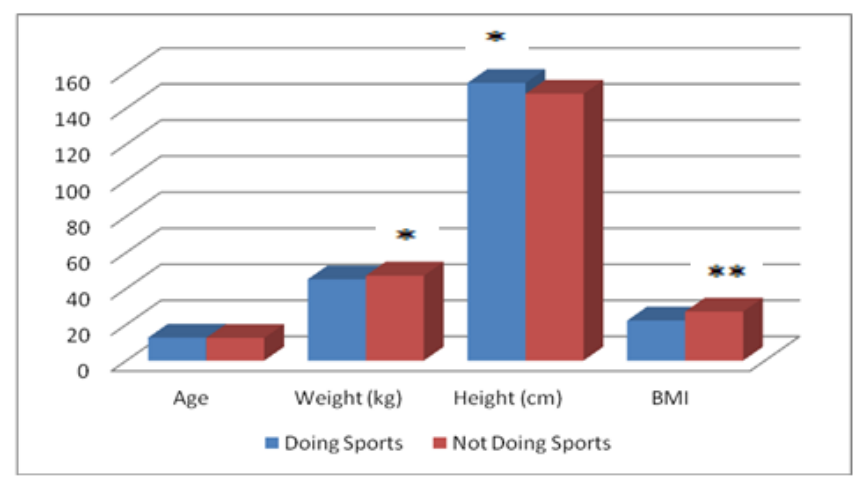

$* \mathrm{P}<0.05, * * \mathrm{P}<0.01$, Body Mass İndex (BMI)

Fig. 2. Demographic Characteristics of Girls with special educational needs

Table 1. Sports Participation Motivation Results of Children Need Special Education

\begin{tabular}{lccccc}
\hline Variables & Sports Participation & $\mathbf{N}$ & SD & $\mathbf{x}^{\mathbf{2}}$ & P Value \\
\hline Internal Motivation & Doing Sports & 30 & 48,22 & & \\
& Not Doing Sports & 30 & 30,75 & 10,972 &, $00 * *$ \\
\hline External Motivation & Doing Sports & 30 & 51,15 & & \\
& Not Doing Sports & 30 & 34,20 & 12,452 &, $00 * *$ \\
\hline Non-Motivation & Doing Sports & 30 & 43,31 & & \\
& Not Doing Sports & 30 & 41,89 & 1,845 &, 73 \\
\hline P $<0.05, \mathrm{P}<0.01^{* *}, \mathrm{SD}$ ( Rank Average) & & & &
\end{tabular}

Table 2. The Relationship Between the Age of Children Needing Special Education and SMPSPD \begin{tabular}{llll}
\hline Variables & Internal Motivation & External Motivation & Non-Motivation
\end{tabular}

\begin{tabular}{llll}
\hline Age &, $282 * *$ &, 172 &,- 08 \\
\hline$(\mathrm{r}=, 282 ; \mathrm{P}<0.05)$ & &
\end{tabular}

Table 3. Investigation of Children's Sports Participation Motivation According to Gender

\begin{tabular}{lcccccc}
\hline Variables & Gender & $\mathbf{N}$ & SD & Mann Whitney U & $\mathbf{Z}$ & $\mathbf{P}$ \\
& & & & & & \\
\hline Internal Motivation & Boys & 30 & 95,41 & 3904,500 &,- 714 &, 81 \\
& Girls & 30 & 96,02 & & & \\
\hline External Motivation & Boys & 30 & 101,18 & 3701,500 &,- 719 &, 43 \\
& Girls & 30 & 99,78 & & & \\
\hline Non-Motivation & Boys & 30 & 43,10 & 532,500 &,- 379 &, 56 \\
& Girls & 30 & 41,42 & & & \\
\hline
\end{tabular}

\section{DISCUSSION}

Studying the trends of recent research on motivation to participate in sports in people with disabilities will shed light on researchers, educators, teachers and children for scientific discussions and inquiries. Because, determining trends by examining and organizing educational research periodically, it is important in terms of shedding light on scientists who want to conduct 
studies in the related field (Cohen, Manion, \& Morrison, 2007). When the concept of motivation is viewed with the logic of turning to sports or directing it, the necessity of making the sport widespread especially among individuals with disabilities and determining the dynamics that can be used in line with this dissemination arises. Individuals can have many different sources of motivation to play sports. These sources of motivation are internal, external and nonmotivational. There are many researches on the motivation of healthy individuals to participate in sports in our country (Ardahan, 2013; Demir \& Cicioğlu, 2018; Hazar, Demir \& Can, 2018; Treasure \& Conroy, 2007). However, the number of studies on disabled people is limited.

In our study, it was determined that the girls and boys participating in sports activities were meaningful in favor of those doing sports when evaluated in terms of height, weight and BMI. It was determined that the average of intrinsic and extrinsic motivation points of the children participating in sports activities was significantly higher than those who did not participate in sports activities. While no significant difference was found according to gender, a positive relationship was found between children age and intrinsic motivation level. Therefore, it can be said that motivation factors are important in participation in sports. Motivation is defined as motivating, activate and encouraging the person to work. Interest in activity plays an important role in increasing motivation to participate in sports. If sports participation activities are not adapted for children in need of special support, participation restrictions may occur (Toptaş Demirci and Demirci, 2018).

Children have different reasons to participate in sports (having fun, developing their skills, exercising, being together and making new friends, competing) boys and girls have similar reasons to participate in sports activities, but these can vary significantly. Although sports participation has the potential to increase psychological well-being, studies suggest that motivation to participate in sports activities has decreased in childhood and adolescence. (Epuran and et al., 2008; Wigfield and et al., 1997). Children participating in sports have been shown to score higher on happiness, mental health and physical health scales than those who do not participate in sports. Regular participation in sports has also been associated with better quality of life (Khan et al., 2012). However, despite all known benefits, children also lead inactive lifestyles in relation to an increased risk of obesity and chronic diseases such as diabetes and coronary artery disease (Nelson et al., 2011). Sports is an important tool to gain the recommended physical activity level for children and young adults (Somerset and Hoare, 2018). As a matter of fact, in addition to supporting all development dimensions of the sport with a social and general approach, there are studies in which it is associated with physical development (Demir et al. 2017).

\section{CONCLUSION}

It was concluded that children with special educational needs have high motivation to participate in sports. The motivation of physical and physiological development comes to the fore in terms of internal motivational orientation factors. Among the external sources of motivation, it has been determined that achieving status and the feeling of success are the most basic elements that activate. Sports is a tool that supports all the development of disabled people in which they can express themselves. It is thought that the sport will serve to popularize among all disabled individuals in the path of socialization. After this research, which attempts to describe the reasons that lead people to sports, new studies to be carried out in different age groups and different types of disabilities should be planned. It is thought that it may create valuable effects in terms of participation in sports and taking measures to encourage individuals to this effective mechanism.

\section{REFERENCES}

Ball, JW., Bice, MR., \& Parry, T. (2014). Adults' Motivation for Physical Activity: Differentiating Motives for Exercise, Sport, and Recreation. RSJ; 38(2).

Ciocan, D.M., Milon, A., \& Mareş, G. (2017). Study Regarding the Motives of Children Participation in Sport Activities. In C. Ignatescu, A. Sandu, \& T. Ciulei (eds.), Rethinking Social Action. Core Values in Practice (pp. 159- 168). Suceava, Romania: LUMEN Proceedings

Cohen, L., Manion, L., \& Morrison, K. (2007). Research methods in education (6th ed.). New York: Routledge. 
Demir, G.T., İlhan, E.L., Cicioğlu, H.I., \& Serkan, K. (2017). Headmaster And Teacher Opinions For Special Olympics Young Athletes Program. Ovidius University Annals, Series Physical Education and Sport/Science, Movement and Health, 17(2), 302-311.

Demirci, N., Yıldırım, İ., Toptaş Demirci, P., \& Ersöz, Y. (2018). Why Should We Do Physical Activity? More Active People for a Healthier World. International Journal of Disabilities Sports \& Health Sciences, 1(2), 1-14.

Epuran, M., Holdevici, I., \& Toniţa, F. (2008). Psihologia Sportului de performanţă, Teorie şi Practică.[Psychology of professional sports. Theory and practice]. Bucharest: FEST Publishing House.

Fredricks, JA., \& Eccles, JS. (2006). Is extracurricular participation associated with beneficial outcomes? Concurrent and longitudinal relations. Developmental Psychology; 42: 698-713.

Golu, M. (2002). Bazele psihologiei generale [Bases of general psychology]. Bucharest: Editura Universitară.

İlhan, E. L. (2010). Culture of Inactive Lives and Their Improvements. National Productivity Center Productivity Journal, 3,195-210.

İlhan, E. L., Esentürk, O. K., \& Yarımkaya, E. (2016). Attitude scale of individuals having mental disabilities towards sports activities (zebseytö): Validity and reliability study. International Journal of Human Sciences, 13(1), 1141-1160.

İlhan, L. (2008). The Effect on the Level of Socialization of Physical Education and Sports in Educable Mentally Handicapped Children. Kastamonu Education Journal, March 16 (1), 315-324.

Jaarsma, A., Dijkstra, P.U., Geertzen, J. H. B., \& Dekker, R. (2014). Barriers to and facilitators of sports participation for people with physical disabilities: A systematic review. Scandinavian journal of medicine ve science in sports, 24(6), 871-881.

Khan, KM., Thompson, AM., Blair, SN., Sallis, JF., Powell, KE., Bull, FC., et al. (2012). Sport and exercise as contributors to the health of nations. Lancet; 380:59-64.

Marcen, C., Gimeno, F., Gomez, C., Saenz, A., \& Gutierrez H. (2013). Socioeconomic Status,
Parental Support, Motivation and SelfConfidence in Youth Competitive Sport. Procedia - Social and Behavioral Sciences; 82: $750-754$.

McDonough, MH., \& Crocker PRE. (2005). Sport Participation motivation in Young Adolescent Girls. Research Quarterly for Exercise and Sport, 76(4): 456-467.

Nelson, TF., Stovitz, SD., Thomas, M., LaVoi, NM., Bauer, KW., \& Neumark-Sztainer, D. (2011). Do youth sports prevent pediatric obesity? A systematic review and commentary. Curr Sports Med Rep;10:36070.

Somerset, S \& Hoare, D.J. (2018). Barriers to voluntary participation in sport for children: a systematic review. BMC Pediatrics; 18:47

Tekkurşun, D. G., İlhan, E. L., Esentürk, O. K., \& Adnan, K. A. N. (2018). Motivation Scale For Sports Participation Of People With Disabilities (Mssppd): A Study Of Validity And Reliability. Spormetre, 16(1), 95-106.

Tenenbaum, G., \& Eklund, R.C. (2007). Exercise adherence. In: Tenenbaum G, Eklund RC, eds. Handbook of sport psychology. Hoboken, NJ: John Wiley ve Sons, Inc., 2007: 516-518.

Toptaş Demirci, P. and Demirci, N. (2018). The Effects Of Game And Physical Activity Lessons In Children With Learning Disabilities. Kinesiologia Slovenica, 24, 3, 47-55.

Wigfield, A., Eccles, JS., Yoon, KS., Harold, RD., Arbreton, AJ., Freedman- Doan, C., \& Blumenfeld PC. (1997). Change in children's competence beliefs and subjective task values across the elementary school years: A 3-year study. Journal of Educational Psychology; 89: 451-469.

World Health Organization (2018). International Classification of Functioning, Disability, and Health: Children \& Youth Version: ICF-CY. Switzerland: World Health Organization.

Yücel, M. (2004). The effect of development and learning on the formation of sports culture. Eastern Anatolia Region Researches, 100108.

How to cite this article: Toptaş Demirci, P. \& Eraslan, K. (2020). Investigation of Participation Motivation in Sports Activities of Children with Special Educational Needs. Int J Disabil Sports Health Sci;3(1):5-10. https://doi.org/10.33438/ijdshs.679613 